\title{
A general scenario of Hox gene inventory variation among major sarcopterygian lineages
}

\author{
Dan Liang ${ }^{1 \dagger}$, Riga $\mathrm{Wu}^{1 \dagger}$, Jie Geng ${ }^{1}$, Chaolin Wang ${ }^{2}$, Peng Zhang ${ }^{1 *}$
}

\begin{abstract}
Background: Hox genes are known to play a key role in shaping the body plan of metazoans. Evolutionary dynamics of these genes is therefore essential in explaining patterns of evolutionary diversity. Among extant sarcopterygians comprising both lobe-finned fishes and tetrapods, our knowledge of the Hox genes and clusters has largely been restricted in several model organisms such as frogs, birds and mammals. Some evolutionary gaps still exist, especially for those groups with derived body morphology or occupying key positions on the tree of life, hindering our understanding of how Hox gene inventory varied along the sarcopterygian lineage.

Results: We determined the Hox gene inventory for six sarcopterygian groups: lungfishes, caecilians, salamanders, snakes, turtles and crocodiles by comprehensive PCR survey and genome walking. Variable Hox genes in each of the six sarcopterygian group representatives, compared to the human Hox gene inventory, were further validated for their presence/absence by PCR survey in a number of related species representing a broad evolutionary coverage of the group. Turtles, crocodiles, birds and placental mammals possess the same 39 Hox genes. HoxD12 is absent in snakes, amphibians and probably lungfishes. HoxB13 is lost in frogs and caecilians. Lobe-finned fishes, amphibians and squamate reptiles possess HoxC3. HoxC1 is only present in caecilians and lobe-finned fishes. Similar to coelacanths, lungfishes also possess HoxA14, which is only found in lobe-finned fishes to date. Our Hox gene variation data favor the lungfish-tetrapod, turtle-archosaur and frog-salamander relationships and imply that the loss of HoxD12 is not directly related to digit reduction.

Conclusions: Our newly determined Hox inventory data provide a more complete scenario for evolutionary dynamics of Hox genes along the sarcopterygian lineage. Limbless, worm-like caecilians and snakes possess similar Hox gene inventories to animals with less derived body morphology, suggesting changes to their body morphology are likely due to other modifications rather than changes to Hox gene numbers. Furthermore, our results provide basis for future sequencing of the entire Hox clusters of these animals.
\end{abstract}

\section{Background}

The Hox genes are a large family of homeobox-containing transcription factors that control morphologies on the body axis of nearly all metazoans. Most of Hox genes normally consist of two exons with the conserved 180-bp homeobox located in exon2. In many animal species, Hox genes are arranged in genomic clusters with up to 15 distinct gene members [1] and, importantly, they are expressed in a "collinear fashion" - anterior genes are expressed early in development and towards the front

\footnotetext{
* Correspondence: alarzhang@gmail.com

† Contributed equally

${ }^{1}$ State Key Laboratory of Biocontrol, Key Laboratory of Gene Engineering of the Ministry of Education, School of Life Sciences, Sun Yat-Sen University,

Guangzhou 510275, China

Full list of author information is available at the end of the article
}

part of the embryo, posterior genes later in development and in more distal portions of the embryo [2]. Due to their important roles involved in patterning the anteriorposterior axis, modifications in Hox clusters might manifest in changes in the corresponding body regions; thus serve as a source of genetic innovations in shaping the diversification of metazoan body plans [3].

Because Hox genes are of particular interest in understanding the genetic basis of morphological evolution of metazoans, they are frequently among the first genes examined in an evolutionary context. Also Hox clusters have been characterized in a variety of animal species. Among chordates, the cephalochordate amphioxus possesses a single intact Hox gene cluster with 15 members [1];
C Biomed Central

(C) 2011 Liang et al; licensee BioMed Central Ltd. This is an Open Access article distributed under the terms of the Creative Commons Attribution License (http://creativecommons.org/licenses/by/2.0), which permits unrestricted use, distribution, and reproduction in any medium, provided the original work is properly cited. 
in urochordate tunicates, the single cluster is secondarily broken and dispersed in the genome [4]. In contrast to these invertebrate chordates, primitive jawless vertebrates (lamprey and hagfish) possess three to seven Hox clusters, most probably through independent cluster duplications in the agnathan lineage [5-7]. Jawed vertebrates also have multiple clusters resulting from several rounds of genomeduplication events that occurred early in the evolution of vertebrates and some specific lineages. There are three or four clusters in chondrichthyans [8-10], four clusters in lobe-finned fishes [11-13] and tetrapods [14,15], up to eight in ray-finned fishes [16-20] and $\sim 14$ in tetraploid salmonid species [21]. The variations in vertebrate Hox clusters reflect a history of duplications and subsequent lineage-specific gene loss and can serve as models for studies of vertebrate genome evolution (reviewed by [14,22]).

For the sarcopterygian lineage (lobe-finned fishes plus tetrapods), all of its members investigated to date bear four clusters $(\operatorname{Hox} \mathrm{A}, \operatorname{Hox} \mathrm{B}, \operatorname{Hox} \mathrm{C}$, and $\operatorname{Hox} \mathrm{D})$ but the number of gene members varies among different groups. Mammals possess 39 Hox genes. For birds, a recent report on genomic annotation of Hox clusters in chicken [23] deduced that birds may have the same Hox gene inventory to mammals but two genes (HoxC4 and Hox C5) are still missing due to the incompleteness of the chicken genome. In silico survey of frog (Xenopus tropicalis) [14] and lizard (Anolis carolinensis) [15] revealed the persistence of $H o x C 3$ (lost in mammals) in both species, but two genes (HoxB13 and HoxD12) are thought to have been lost in anuran amphibians. Recent relevant studies have further reported that the absence of HoxB13 in frogs also occurs in caecilians, and the loss of HoxD12 in frogs also happens in salamanders, caecilians [24] and snakes [25]. Most recently, the complete Hox clusters of the Indonesian coelacanth (Latimeria menadoensis), an early-branching sarcopterygian, have been sequenced [13]. Compared to the tetrapod lineage, the coelacanth possesses 42 Hox genes in total, lacking $\operatorname{HoxD13}$, but retaining the four genes (HoxC1, $H o x C 3, H o x B 10$, and HoxA14) which were secondarily lost in mammals.

However, our knowledge of the Hox genes and clusters along the sarcopterygian lineage remains incomplete because data from some major groups are still missing (illustrated in Figure 1). For example, it is curious to see whether lungfishes possess Hox 14 and lost HoxD13 in their genomes (available data is rather incomplete, see [11]) as coelacanths. On the other hand, a "snake-like" morphology (limblessness and elongated body) repeatedly occurs in different groups of amphibians and reptiles, such as snakes, caecilians and some legless lizards. There were published reports suggesting the "snakelike" body morphology may be due to altered expression of Hox genes [25-27]. Comparative analyses on the Hox

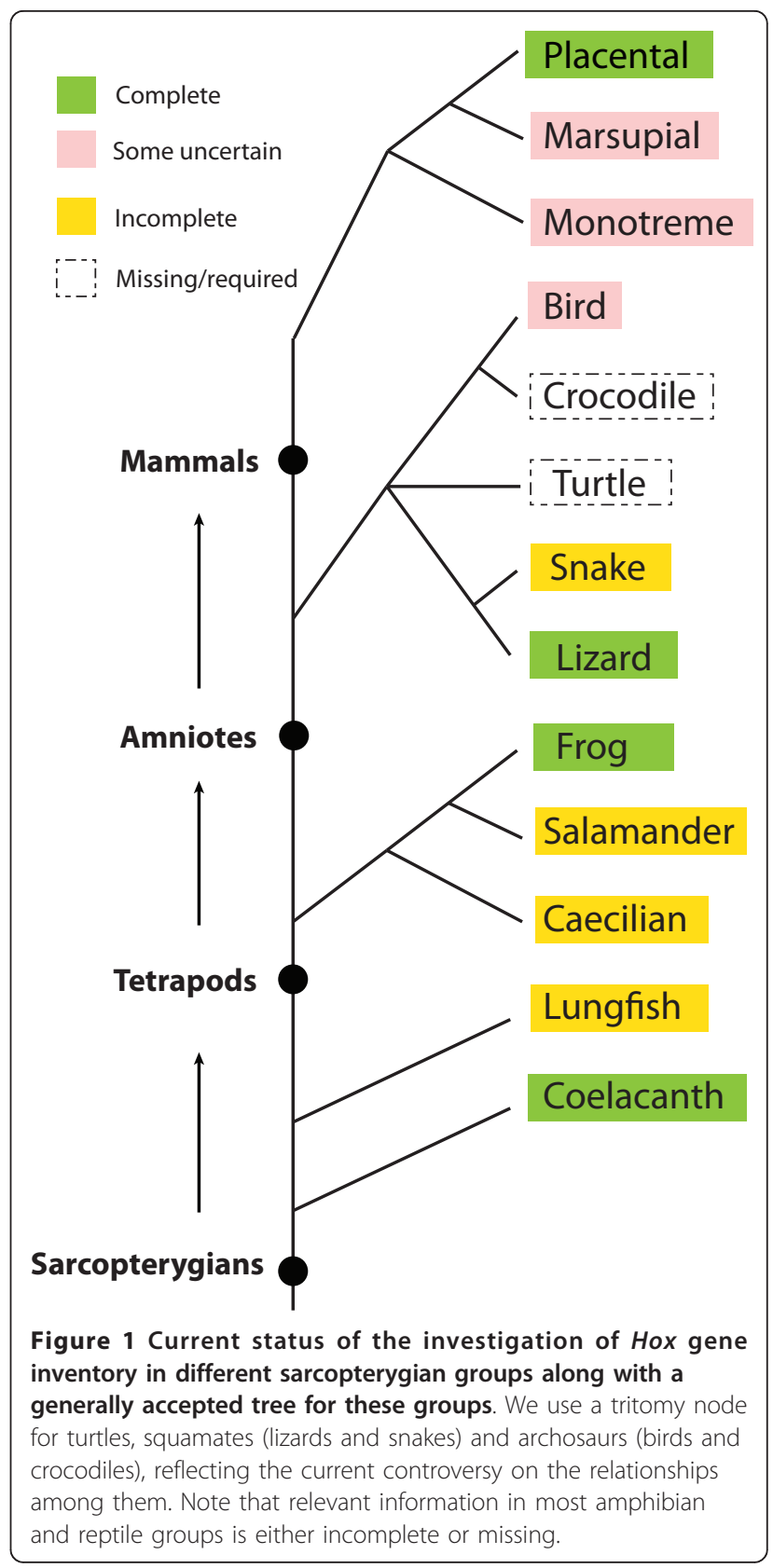

clusters among these special groups should be able to provide further hints on how such expression alterations happen. For sequencing of the Hox clusters, a framework investigation of Hox gene inventory in these groups (snakes, caecilians, et al.) is needed.

PCR surveys have demonstrated their value for preliminary identification of Hox genes in various animals $[6,11,12,24]$. However, PCR surveys of Hox genes often encounter a bias of the preference of degenerate primers and therefore, the actual number of existing genes is underestimated $[6,24]$. To circumvent this problem, we designed at least two sets of degenerated primers 
targeting a given Hox gene member, which increased the probability of successful amplification. Furthermore, when possible, we selected at least two species that span a broad evolutionary range for each tested groups, for which the primer preference may be different, maximizing the probability of finding all genes for a group. By adopting the two strategies, we carried out a comprehensive PCR survey for Hox genes in caecilians, salamanders, snakes, turtles, crocodiles, and lungfishes-the only other group of extant lobe-finned fishes beside coelacanths. We aimed to provide a more comprehensive understanding of Hox cluster evolution within the sarcopterygian lineage and present a general picture of $H o x$ gene inventory variation among different sarcopterygian groups.

\section{Results and Discussion}

Amplification and Identification of Hox gene fragments For each of the six sarcopterygian species examined, we tried different combinations of the degenerate primers, some targeted to several paralogue groups (PGs), some to specific groups and others to specific gene members, to amplify the homeobox-encoding region or exon 1 of Hox genes (Table 1). We did several rounds of PCR first using "general" degenerate primers, and then using more specific primers designed for paralogue groups or gene members that were not found in the initial survey. A total of 3876 PCR fragments ( 80 to 165 bp long, depending on the primers used) were cloned and sequenced. Detailed information about the library construction and screening efficiency for the six sarcopterygian species and other relevant species is listed in the Additional file 1: Statistics of the sequenced clones. Occasionally, two sequences were found differing in only one to three nucleotides. When the nucleotide variations belong to synonymous substitutions and each of these sequences was present in more than one clone, they were considered as allelic variants. Conversely, non-synonymous substitutions of one or two nucleotides in only one clone but not the others of the same fragment were regarded as PCR or sequencing errors and excluded from further analyses.

Initial BLAST searches in GenBank indicated that 82.9-96.5\% sequenced clones belonged to Hox fragments, depending on the animal species examined. This result demonstrated the utility and efficiency of our newly designed Hox survey primers across most sarcopterygian lineages. Based on the phylogenetic analyses at the protein level, we can unambiguously assign $70-75 \%$ of the obtained homeobox sequences to exact Hox gene members. The phylogenetic signals in protein alignments of Hox2, Hox6-8 were especially weak so that the phylogenetic analyses at the nucleic acid level were performed to putatively distinguish Hox members for these paralogue groups. Using this strategy, we were able to determine the orthology of all obtained Hox fragments.

To test the credibility of our assignment of putative $H o x$ fragments based on the nucleic acid phylogenetic analyses, we chose two species (Naja atra and Ichthyophis bannanicus) to perform the TAIL-PCR-based genome walking to get the 3' flanking sequences of their putative Hox6-8 fragments. The newly obtained sequences were compared with known sarcopterygian Hox genes, and all the assignments were verified.

\section{Hox gene inventories of different animal groups Lungfishes}

Protopterus annectens, the African lungfish, was found to have a total of 42 Hox genes orthologous to genes of the four coelacanth Hox clusters. Generally the Hox inventory of the African lungfish is quite similar to that of the coelacanth (Latimeria menadoensis) [13], for example, they both possess $\mathrm{HoxC}_{\mathrm{C}}, \mathrm{HoxC} 3$ and $\mathrm{HoxB10}$; but interestingly the African lungfish lacks $\operatorname{HoxD} 12$ while the coelacanth has no HoxD13. Moreover, because the coelacanth has a HoxA14 gene and chondrichthyans have a HoxD14 gene $[9,10]$ but all tetrapod species examined so far lack Hox-14, we wonder if Hox 14 member also exist in lungfishes and/or the basal tetrapod lineage, i.e. caecilians. To this end, an 84-bp-fragment conserved only in Hox 14 was tested by PCR in the African lungfish and the Banna caecilian and only the African lungfish gave the band with expected size, suggesting that Hox14 may have been lost in all tetrapods. However, no further assignment could be made for the lungfish Hox 14 fragment because of its short size. We thus performed genome walking towards both ends of this Hox 14 fragment and got full sequence of the exon2 of the lungfish Hox14. Using the lamprey Hox14 alpha as outgroup, phylogenetic analysis unambiguously assigned the lungfish's Hox14 member as a HoxA14 (Figure 2). Among all vertebrates investigated to date, only the coelacanths and the lungfishes which represent the only two groups of the extant lobe-finned fish possess HoxA14. Thus, HoxA14 seems to be characteristic of the lobe-finned fish $H o x$ repertoire.

\section{Caecilians}

In the Banna caecilian (Ichthyophis bannanicus) 39 unique Hox gene fragments were found. Besides the core set of Hox genes (using mammals' as reference), we identified a $\mathrm{HoxC1}$ fragment as well as a HoxC3 fragment in the Banna caecilian. The presence of HoxC1 in caecilians was further validated by screening the Hox 1 library (see the Additional file 1: Statistics of the sequenced clones) in Gymnopis multiplicata, a representative of derived caecilians. Because HoxC3 was also found in the frog (Xenopus tropicalis; [15]) and the salamander (our survey, see below), it seems that all living 
Table 1 Primers used for amplification of Hox gene fragments

\begin{tabular}{|c|c|c|c|c|c|}
\hline Target gene & Primer name & Sequence $\left(5^{\prime}-3^{\prime}\right)$ & AA sequences & $\mathrm{PL}^{*}(\mathrm{bp})$ & Notes \\
\hline \multicolumn{6}{|c|}{ Forward primers (located at homeobox region) } \\
\hline PG1-PG7 & HoxF1 & TNGARYTNGARAARGARTTYCA & LELEKEFH & 125 & universal for PG1-PG7 \\
\hline \multirow[t]{2}{*}{ PG1-PG10 } & HoxF1N1 & CARACNYTNGARYTNGARAARGARTT & QTLELEKEF & 128 & universal for PG1-PG10 \\
\hline & HoxF1N2 & CARGTNACNGARYTNGARAARGARTT & QLTELEKEF & 128 & universal for PG1-PG10 \\
\hline PG5-PG7 & HoxF7S & CARACNTAYACNMGNTAYCARAC & QTYTRYQT & 149 & universal for PG5-PG7 \\
\hline \multirow[t]{2}{*}{ PG8-PG10 } & HoxF8 & TNGARAARGARTTYYTNTTYAA & LEKEFLFN & 120 & universal for PG8-PG10 \\
\hline & HoxF8N & TNGARYTNGARAARGARTTYYT & LELEKEFL & 125 & universal for PG8-PG10 \\
\hline PG9-PG11 & HoxF9 & DSNMGNAARAARVGNTGYCCNTA & TRKKRCPY & 164 & universal for PG9-PG11 \\
\hline PG1 & HoxF1S & AAYTTYACNACNAARCARYTNAC & NFTTKQLT & 149 & universal for PG1 \\
\hline PG2 & HoxF2S & MGGACNGCNTAYACNAAYACNCA & RTAYTNTQ & 152 & specific for PG2 \\
\hline \multirow[t]{2}{*}{ PG3 } & HoxF3S & GCNTAYACNAGYGCNCARYTNGT & AYTSAQLV & 149 & specific for PG3 \\
\hline & HoxF3S1 & MGVCCNMGVMGVBTNGARATGGC & RPRRVEMA & 80 & specific for PG3 \\
\hline PG4 & HoxF4S & ACNGCNTAYACNMGNCARCARGT & TAYTRQQV & 152 & specific for PG4 \\
\hline \multirow{2}{*}{ PG5 } & HoxF5S & GGNAARMGSGCNMGSACNGC & GKRARTA & 165 & specific for A5, B5 \\
\hline & HoxFC5 & AARCGNTCYMGAACNAGYTAYAC & KRSRTSYT & 160 & specific for $\mathrm{C} 5$ \\
\hline PG8 & HoxF8S & GARAARGARTTYYTNTTYAAYCC & EKEFLFNP & 116 & specific for PG8 \\
\hline PG9 & HoxF9S & GARAARGARTTYYTNTTYAAYATG & EKEFLFNM & 116 & specific for PG9 \\
\hline PG10 & HoxF10S & AARMGNTGYCCNTAYACNAARCA & KRCPYTKH & 152 & specific for PG10 \\
\hline PG11 & HoxF11 & GARYTNGARMGNGARTTYTTYTT & ELEREFFF & 122 & specific for PG11 \\
\hline \multirow[t]{6}{*}{ PG12 } & HoxF12 & DSNMGNAARAARVGNAARCCNTA & SRKKRKPY & 164 & specific for PG12 \\
\hline & HoxF12C & AARCCNTAYTCNAARYTNCARAT & KPYSKLQL & 149 & specific for $\mathrm{C} 12$ \\
\hline & HoxF12D & AARCCNTAYACNAARCARCARAT & KPYTKQQI & 149 & specific for D12 \\
\hline & HoxF12N1 & KCNMGVAARAARMGVAARCCSTA & SRKKRKPY & 164 & specific for PG12 \\
\hline & HoxF12N2 & KCNMGVAARAARMGVAARCCWTA & SRKKRKPY & 164 & specific for PG12 \\
\hline & HoxF12N3 & KCNMGVAARAARMGVAARACNTA & SRKKRKTY & 164 & specific for PG12 \\
\hline \multirow[t]{4}{*}{ PG13 } & HoxF13A & GGNMGNAARAARMGNGTNCCNTA & GRKKRVPY & 164 & specific for PG13(A,C,D) \\
\hline & HoxF13B & GGNMGNAARAARMGNATHCCNTA & GRKKRIPY & 164 & specific for PG13(B) \\
\hline & HoxF13A1 & CARYTRAARGARCTNGARMGNGARTA & QLKELEREY & 128 & specific for PG13(A) \\
\hline & HoxF13B1 & CARYTRAARGARCTNGARAANGARTA & QLKELENEY & 128 & specific for PG13(B,C,D) \\
\hline \multicolumn{6}{|c|}{ Reverse primers (located at homeobox region) } \\
\hline PG1-PG12 & HoxR1 & TTCATNCKNCKRTTYTGRAACCA & WFQNRRMK & - & universal for PG1-PG12 \\
\hline PG13 & HoxR13 & TTNACNCKNCKRTTYTGRAACCA & WFQNRRVK & - & specific for PG13 \\
\hline PG14 & HoxR14 & TCNGGNGTNAGRAANCGRTTYTC & ENRFLTPE & 89 & specific for PG14, used with HoxF13A/HoxF13B \\
\hline \multicolumn{6}{|c|}{ Primers used for amplification of exon 1 of Hox genes } \\
\hline \multirow[t]{2}{*}{ PG1 } & HoxB1 $\left(5^{\prime} E 1\right) F$ & GACATASTRYCNAAAGGTTGTAG & $5^{\prime}$ UTR & $590-630$ & forward primer for HoxB1 \\
\hline & $\operatorname{HoxB1}(\mathrm{E} 1) \mathrm{R}$ & TTAACYTTCATCCANTCRAANGT & TFDWMKVK & - & reverse primer for HoxB1 \\
\hline \multirow[t]{2}{*}{ PG2 } & $\operatorname{Hox} 2 \mathrm{~S}(\mathrm{E} 1) \mathrm{F}$ & GAATTYGAGMGRGARATHGGNTT & EFEREIGF & $270-300$ & forward primer for PG2 \\
\hline & $\operatorname{Hox} 2 \mathrm{~S}(\mathrm{E} 1) \mathrm{R}$ & YTTYTTCTCYTTCATCCANGG & PWMKEKK & - & reverse primer for PG2 \\
\hline \multirow[t]{5}{*}{ PG3 } & $\operatorname{Hox3S(E1)F}$ & ATGCARAAARCRRCNTAYTAYGA & MQKATYYD & $400-480$ & forward primer for PG3 \\
\hline & $\mathrm{HoxC3}(\mathrm{E} 1) \mathrm{F}$ & ATGCAAAARGSTCYYTAYTAYGA & MQKGPYYE & $400-480$ & forward primer for $\mathrm{HoxC} 3$ \\
\hline & HoxA3(E1)F & GCGACCTACTAYGAYAGYTCNGC & ATYYDSSA & $390-470$ & forward primer for HoxA3 \\
\hline & HoxD3(E1)F & ATGCAGAAARCNGCYTAYTAYGA & MQKTAYYD & $400-480$ & forward primer for HoxD3 \\
\hline & $\operatorname{Hox3S(E1)R~}$ & TCYTTCATCCANGGRAADATNTG & QIFPWMKE & - & reverse primer for PG3 \\
\hline \multirow[t]{2}{*}{ PG6 } & HoxB6(5'E1)F & AWACTRCTAATAGCTAAASCRCT & $5^{\prime}$ UTR & $480-510$ & reverse primer for HoxB6 \\
\hline & $\operatorname{Hox6S(E1)R~}$ & GARTTCATCCKYTGCATCCANGG & PWMQRMNS & - & reverse primer for PG6 \\
\hline \multirow[t]{2}{*}{ PG7 } & $\operatorname{HoxB7}\left(5^{\prime} \mathrm{E} 1\right) \mathrm{F}$ & CTCGTAAAACCGACACTAAAACG & $5^{\prime}$ UTR & $440-460$ & forward primer for HoxB7 \\
\hline & $\operatorname{Hox} 7 \mathrm{~S}(\mathrm{E} 1) \mathrm{R}$ & CATCCARGGGTADATNCGRAA & FRIYPWM & - & reverse primer for PG7 \\
\hline
\end{tabular}

\footnotetext{
* PL: Product length.
} 
a.

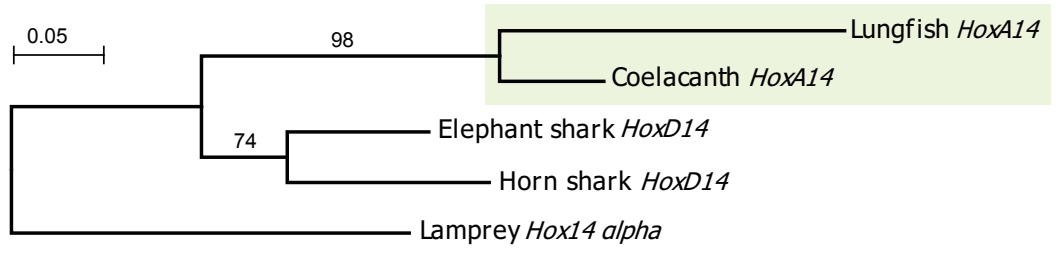

b.

Lungfish HoxA14

Coelacanth HoxA14

Elephant shark HoxD14

Horn shark HoxD14

Lamprey Hox14 alpha

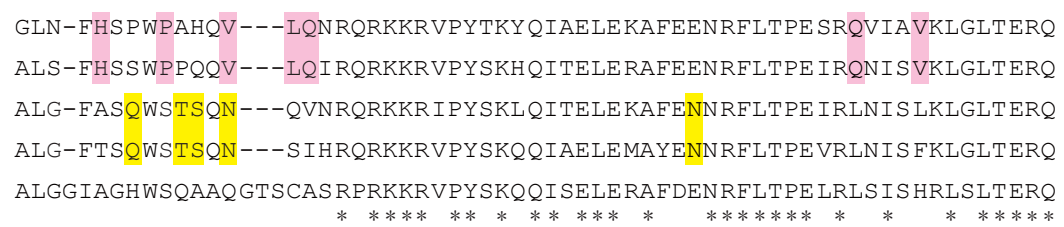

Figure 2 Characterization of the exon2 of the lungfish HoxA14 gene. (a) Neighbor-joining tree inferred from deduced protein sequences of the exon2 of Hox14 gene with JTT distance. Exon2 of Hox14 from lungfish (Protopterus annectens), coelacanth (Latimeria menadoensis), elephant shark (Callorhinchus milii) and horn shark (Heterodontus francisci) are included and the lamprey (Lethenteron japonicum) Hox 14 alpha is used to root the tree. Bootstrap supports are given for each node above branches. (b) Protein alignment of Hox 14 exon2 from the five species. Residues that are conserved in all species are indicated with asterisks below the alignment and that are diagnostic for HoxA14 or HoxD14 are highlighted with pink or yellow shading respectively.

amphibians retain HoxC3. Therefore we did not perform further survey for HoxC3 in other caecilian species. In addition, after having tried different combinations of primers, we could not find fragments of HoxD12 and HoxB13 in the three tested caecilian species (I. bannanicus, G. multiplicata, and Typhlonectes natans; see the Additional file 1: Statistics of the sequenced clones) which is consistent with the loss of HoxD12 and HoxB13 in caecilians previously reported by Mannaert et al. [24].

\section{Salamanders}

Compared with other animal groups, surveying the Hox gene inventory for salamanders was more difficult. We tried several species but in none of them could we find more than thirty-three Hox genes. In order to give a more integrated Hox gene inventory of salamanders, we combined the results from two species (Batrachuperus tibetanus and Pachytriton brevipes) to represent the group. Initial PCR survey of homeobox fragments in Batrachuperus tibetanus, the Tibetan mountain salamander, identified 33 Hox gene fragments after sequencing over 770 clones. Compared with the frog $H o x$ complement, HoxA1, HoxA3, HoxD3, HoxB6, HoxB7 and $H o x A 10$ were missing. The missing $H o x$ genes were further surveyed in another salamander Pachytriton brevipes and two more Hox members (HoxA1 and HoxA10) were detected after sequencing 220 clones. To validate the potential presence of the remaining Hox members, we turned to detect their respective exon1s and finally fragments of HoxA3, HoxD3, HoxB6 and HoxB7 were found. Consistent with the previous reports of the presence of HoxB13 in salamandrids [24] and ambystomatids [Genbank: AF298184], we identified HoxB13 in the more basal hynobiid salamander (B. tibetanus), suggesting the presence of $H o x B 13$ is likely a universal feature of all salamanders. Likewise, we did not detect HoxD12 in all salamanders investigated (see the Additional file 1: Statistics of the sequenced clones), in accordance with the previous survey result [24]. Altogether, salamanders have 39 Hox genes with the presence of $H o x C 3$ and absence of HoxD12 and unlike the other two amphibian groups, salamanders possess HoxB13.

Frogs

The genomic architecture of Hox clusters of the frog (Xenopus tropicalis, a diploid frog species) has been previously reported [15] but $\operatorname{HoxB7}$ was not detected in its genome due to a sequencing gap. However, HoxB7 mRNA was cloned in another frog (Xenopus laevis; accession: NM_001085641), indicating that frogs possess HoxB7 gene. In total, frogs have 38 Hox genes, lacking HoxB13 and HoxD12, but retaining HoxC3.

\section{Lizards and Snakes}

Di-Poï et al. [15] analyzed the genome data of the green anole lizard (Anolis carolinensis) and reported that lizards have $40 H o x$ gene with an additional HoxC3 gene which is absent in mammals. However, HoxB13 and $H o x D 9$ were only deduced genes in their study, not directly detected due to some sequencing gaps. We reanalyzed the flanking sequences of these gaps and identified fragments orthologous to $\operatorname{HoxB13}$ (exon2) and HoxD9 (exon1), improving the completeness of lizards' Hox gene inventory. 
For snakes, we found 39 unique Hox sequences in the Chinese cobra (Naja atra). Like lizards, snakes also have a HoxC3 gene. To see if the presence of HoxC3 is a characteristic of all squamates, we further surveyed the Hox-3 genes in two other squamate species: gecko (Hemidactylus bowringii) and blind skink (Dibamus bourreti), belonging to two basal squamate groups Gekkonidae and Dibamidae, respectively. As a result, fragments of HoxC3 were unambiguously identified in the two species (see the Additional file 1: Statistics of the sequenced clones), suggesting all squamates should possess HoxC3.

Despite HoxD12 having been annotated in the green anole lizard, we did not detect HoxD12 fragment in the Chinese cobra after screening the Hox 12 libraries constructed with different primer pairs. Absence of HoxD12 has just been reported in the corn snake recently [25]. Since both the Chinese cobra and the corn snake belong to derived snakes, to further test if HoxD12 is absent in all snakes, we surveyed Hox12 in two other snakes: blind snake (Leptotyphlops blanfordii) and ball python (Python regius) which occupy more basal positions on the Serpentes tree and might be able to circumvent the Hox12-specific primer bias if there were any. As a result, only HoxC12 fragment could be found in these two snakes as well (see the Additional file 1: Statistics of the sequenced clones). Therefore, it is likely that snakes have lost HoxD12.

\section{Turtles}

Pelodiscus sinensis, which is also known as the Chinese soft-shell turtle, was found to have 39 Hox genes, lacking HoxC3 compared with lizards. Since the squamate reptiles investigated so far have retained $H o x C 3$, we wondered if the missing of HoxC3 in turtles was due to primer bias. So we surveyed Hox3 genes in another four turtles: the yellow-spotted Amazon river turtle (Podocnemis unifilis), the pig-nosed turtle (Carettochelys insculpta), the painted turtle (Chrysemys picta) and the red-eared slider turtle (Trachemys scripta), which were particularly selected to represent a broad evolutionary coverage for turtles. As a result, no fragments of HoxC3 could be identified (see the Additional file 1: Statistics of the sequenced clones), which is consistent with the loss of $\mathrm{HoxC} 3$ in turtles.

\section{Crocodiles}

For the Siamese crocodile (Crocodylus siamensis), most Hox genes were found as expected using the chicken Hox gene inventory [23] as reference. However, only one homeobox fragment was retrieved for Hox 2 which usually contains two members (HoxA2 and HoxB2) though several primer combinations have been tried. Because the loss of HoxA2 or HoxB2 has never been reported in other vertebrates, we used primers targeting exon 1 for $H o x A 2$ and $H o x B 2$ and were able to identify specific fragments for both genes in the Siamese crocodile. In addition, HoxC3 was not detected in the Siamese crocodile and its absence in crocodiles was further validated in the Chinese alligator (Alligator sinensis; see the Additional file 1: Statistics of the sequenced clones), a representative of the other major clade of living crocodiles. Thus crocodiles have 39 Hox genes and their Hox gene inventory is the same as that of mammals.

\section{Birds}

Though the genomic annotation of Hox clusters has been reported for the chicken (Gallus gallus), information for HoxC4 and HoxC5 is still missing due to incomplete genomic assembly $[15,23]$. And because of the gap at the 3' end of the HoxC cluster in the chicken genome, we do not know whether chicken has HoxC3 or not. Besides, we found the homeobox of the predicted chicken HoxC12 [Genbank: XM_426957] differs a lot from its orthologs in other vertebrates and may have assembly errors. In our PCR survey we confirmed the presence of chicken HoxC4 and HoxC5 by finding their respective homeobox fragments. To test whether birds retain $H o x C 3$, we surveyed Hox3 genes in two birds: the domestic duck (Anas platyrhynchos var. domestica) and the ostrich (Struthio camelus), representing two major bird lineages (Neognathae and Paleognathae) respectively. As a result, HoxC3 was not detected, suggesting it was lost in birds (see the Additional file 1: Statistics of the sequenced clones). The reexamination of Hox12 in chicken, duck and ostrich confirmed the presence of HoxD12 in birds and revealed a fragment appearing well

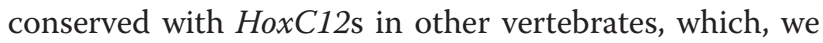
think, represents the true bird HoxC12 (see the Additional file 1: Statistics of the sequenced clones). Hence, with the detection of HoxC4, HoxC5, HoxC12 and HoxD12 in birds, our data provides a more complete picture of avian Hox gene inventory.

\section{Mammals}

Although the Hox gene inventory for placental mammals (e.g., human and mouse) is clear, the relevant information for the other two major groups of extant mammals: marsupials, monotremes, has not been reported yet. We therefore performed an in silico survey of Hox genes for the grey short-tailed opossum Monodelphis domestica (version Broad/monDom5; URL: http://genome.ucsc.edu/cgi-bin/hgGateway?org=Opossum) and the duck-billed platypus Ornithorhynchus anatinus (version WUGSC 5.0.1/ornAna1; URL: http:// genome.ucsc.edu/cgi-bin/hgGateway?org=Platypus). In both species, the $\operatorname{Hox} \mathrm{A}, \mathrm{B}$, and D clusters are almost identical to those in human (HoxB6 was not detected in the platypus due to a sequencing gap). For the $H o x C$ cluster, the platypus lacks genomic sequences covering HoxC5, HoxC4 and its 3' flanking region; the opossum lacks almost the entire genomic sequences of the $H o x C$ 
cluster, except fragments of HoxC6 and HoxC9. Based on the observation that the architecture of $\mathrm{HoxC13}-\mathrm{C} 4$ is conserved among all tetrapods, it is tempting to infer that marsupials and monotremes possess the same $H o x C$ members as well. However, because the genomic sequences of the 3' flanking region of HoxC4 in both the opossum and the platypus are still missing, it would be premature to derive any conclusions about the presence/absence of $\mathrm{HoxC} 3$ in marsupials and monotremes.

\section{The general scenario}

Combining our data with other published data, we are now able to provide a more complete scenario of how Hox gene inventory variation occurs along major sarcopterygian lineages, from lobe-finned fishes to mammals (Figure 3). On the whole, the four-cluster Hox architecture is well conserved; relatively basal lineages tend to retain more Hox gene members. The HoxA14, B10, C1, $C 3$ were consecutively lost during the process of sarcopterygian evolution. HoxD12 and HoxB13 seem to be two hotspots of gene loss and different animal groups may have lost these Hox genes independently.

\section{Hox gene variation among sarcopterygian lineages and its evolutionary implications}

The loss of HoxD12 is not directly related to digit reduction

Mannaert et al. [24] have proposed the absence of HoxD12 in amphibians be related to the absence of the fifth finger as frogs and salamanders normally have only four fingers and caecilian is limbless. In such a view, HoxD12 would be frequently lost in limbless animals (no digits at all). The hypothesis seems reasonable because HoxD12 does be lost in the snake (limbless, no digits) and the African lungfish (only with thread-like fins) according to our Hox gene survey. However, besides snakes, there are many other squamates with snake-like, limbless body forms. It is necessary to test the hypothesis more strictly in these limbless animals as well. To this end, we further surveyed Hox 12 genes in other limbless lizards, such as Amphisbaena caeca (Amphisbaenidae), Blanus strauchi (Blanidae), Ophisaurus harti (Anguidae), Anniella pulchra (Anniellidae), Typhlosaurus sp. (Scincidae) and Dibamus bourreti (Dibamidae), representing a broad evolutionary coverage for squamates. To our surprise, both $\mathrm{HoxC12}$ and $\mathrm{D} 12$ could be unambiguously detected in all these limbless animals (see the Additional file 1: Statistics of the sequenced clones). This result indicated that the loss of HoxD12 is not as directly related to the digit-reduction phenotype as previously proposed.

\section{The significance of HoxD13 retention in lungfishes}

While the other group of extant lobe-finned fish, the coelacanths, has lost HoxD13 [13], a HoxD13 fragment was identified from the African lungfish in our PCR survey. Previous knock-out experiments in mice have demonstrated that
HoxD13 is essential in the autopodium formation for tetrapods $[28,29]$, so it is easy to understand the fact that all tetrapods investigated so far possess the HoxD13 gene. Therefore, the retention of HoxD13 which is shared by tetrapods and lungfishes but not coelacanths, is consistent with lungfishes being the closest living sistergroup of tetrapods, a widely accepted relationship among coelacanths, lungfishes and tetrapods [30].

Strictly, small Hox gene fragments generated by PCR surveys are not definite evidences for the absence/presence of a gene, for example, the HoxD13 fragment in the goldfish Carassius auratus auratus is thought to represent a pseudo gene [31]. Therefore, we wonder whether the African lungfish HoxD13 is really a functional gene. To address this issue, genome walking was performed to obtain the 5 ' region of the homeobox of the lungfish $\operatorname{HoxD13}$, including the intron and the complete exon1. No premature stop codons were observed, indicating the African lungfish HoxD13 is not a pseudo gene. Sequence alignments and phylogenetic analysis show that, the tetrapod HoxD13s are more similar to the African lungfish HoxD13 than to that of bony fishes (zebrafish) or cartilaginous fishes (shark) (Figure 4). Although the lungfish has no "digits", its HoxD13 may represent the intermediate form towards the functions in tetrapod HoxD13s during the fin-to-limb transitional history. In the future it would be interesting to perform "replacement" experiments in mice to see to what extent the lungfish $H o x D 13$ could rescue the functions of the tetrapod HoxD13 especially in terms of autopodium formation.

The variation of HoxC3 shows clues for turtles' position on the amniote tree

The phylogenetic position of turtles is the most controversial issue in the reconstruction of the living amniote tree of life. After many different kinds of investigations from both molecular and morphological data, four main hypotheses concerning the phylogenetic relationships of turtles to the other groups of living amniotes have been proposed [30]: $(A)$ Turtles as the only living representatives of anapsid reptiles, and as the sister-group of diapsid reptiles, i.e., the Lepidosauria (the tuatara, snakes, and lizards) + Archosauria (crocodiles and birds); $(B)$ Turtles placed within diapsids, and as the sistergroup of the Lepidosauria; $(C)$ Turtles as diapsids, and as the sister-group of the Archosauria; $(D)$ Turtles as diapsids, but placed inside the Archosauria, and as the sister-group of crocodiles. Most morphological studies favor either Hypothesis $A$ [32-35] or $B$ [36,37] and Hypothesis $A$ is the traditional view of the placement of turtles. In contrast to morphological views, recent molecular phylogenetic studies tend to support either Hypotheses $C$ or $D$ and reject Hypotheses $A$ and $B$ [38-43]. However, due to a severe slow down of 


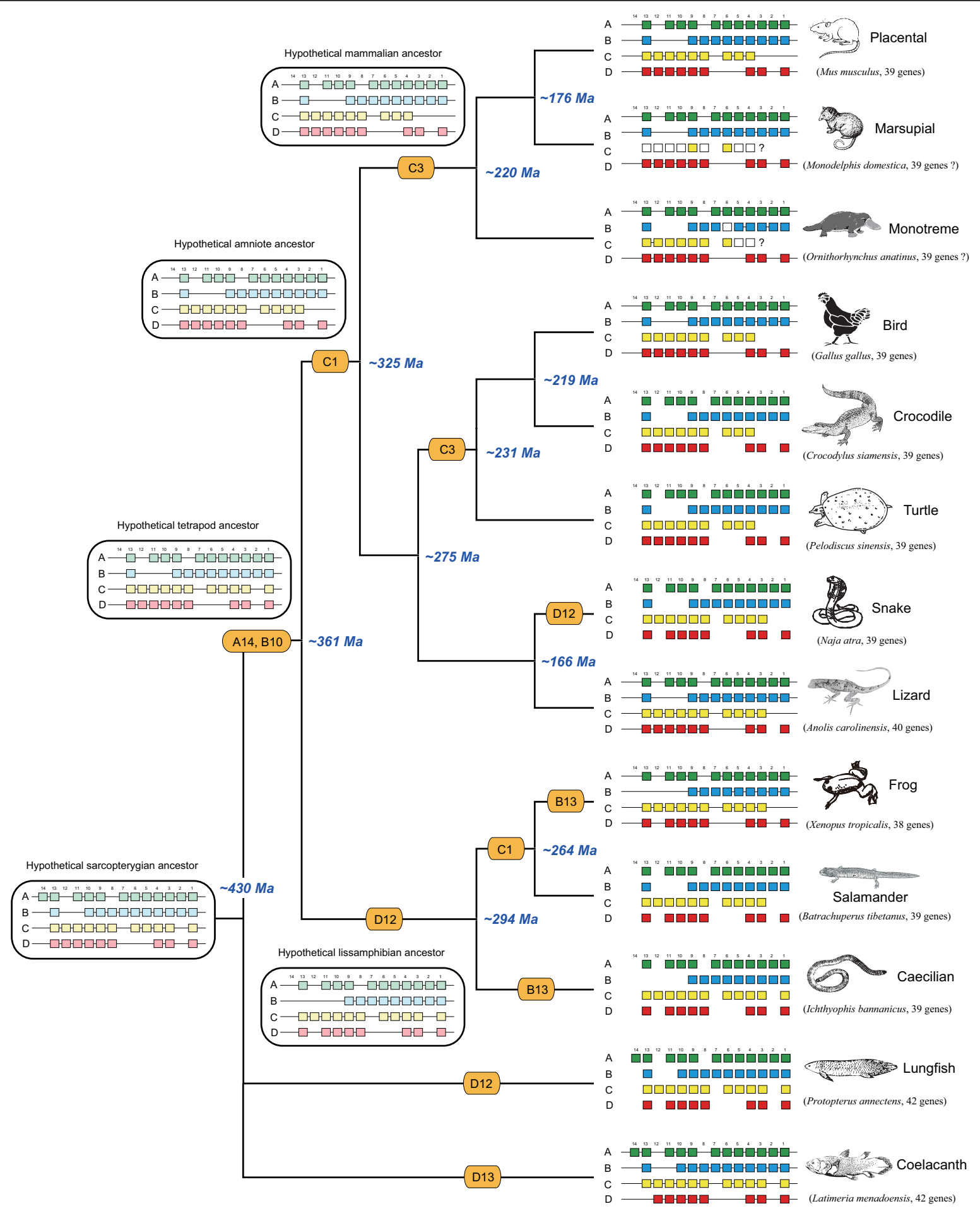

Figure 3 Reconstructed evolutionary history of Hox cluster evolution within the sarcopterygian vertebrates. Colored squares indicate Hox genes that have been identified; white squares are Hox genes that have not yet been sequenced but probably are present in the cluster(s). Solid lines connecting gene boxes indicate physical genomic linkage. Genomic sequences flanking HoxC3 gene in both opossum and platypus are still missing thus we consider the presence/absence of HoxC3 in marsupial and monotreme mammals is unknown yet (indicated by question marks). The gene inventory of the Hox clusters in the hypothetical ancestors of major evolutionary lineages are inferred based on parsimony principles, shown in open boxes above branches. Secondary losses of Hox genes are indicated in orange boxes along branches. A currently accepted phylogenetic tree is shown on the left, with divergence times (taken from [51]) shown beside nodes. Note that we tentatively favor a turtle-archosaur relationship based on HoxC3 variation among different amniote groups (see text for detailed discussion). 


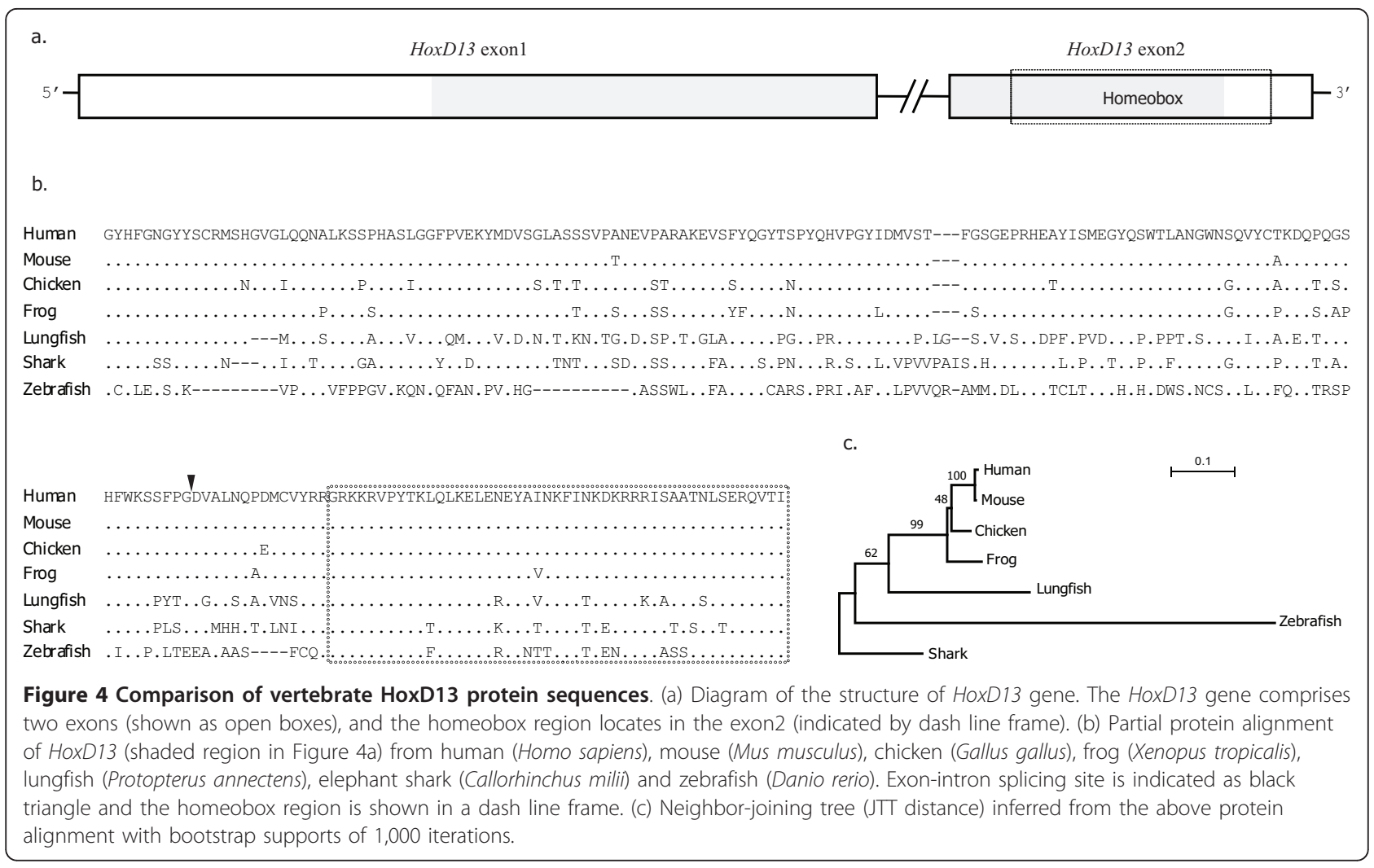

substitution rate in turtles relative to diapsid reptiles [43], we can not rule out the possibility that the molecular turtle-archosaur relationship is caused by analytical artifacts. Therefore, besides traditional morphological inferences and sequence-based molecular phylogenetic analyses, a third form of data is needed to explore and test the alternative phylogenetic hypotheses of the turtle's placement.

The presence of $\mathrm{Hox} C 3$ gene among living amniote lineages seems a good indicator of their interrelationships. Since both lobe-finned fishes and amphibians possess $\mathrm{HoxC} 3$, the presence of $\mathrm{HoxC} 3$ is most likely the ancestral state for amniotes. According to our survey, for living amniotes, only squamates (snakes and lizards) retained HoxC3 (the tuatara data is missing here, but it will not alter our inference due to its affinity to squamates) and other groups (mammals, birds, crocodiles and turtles) all lost this gene. Following the principle of Dollo parsimony which assumes that losses of genes are much more common and likely than independent evolutionary origins, - we can evaluate the four hypotheses about the position of turtles mentioned above. Both Hypotheses $A$ and $B$ require 3 steps of independent loss of $\mathrm{HoxC} 3$ in mammals, turtles and archosaurs while Hypotheses $C$ and $D$ need only two steps. Consequently, our Hox gene inventory data is in line with most recent molecular studies favoring a turtle-archosaur relationship but unable to discriminate between
Hypotheses $C$ and $D$. Considering that Archosauria is a well supported clade, we tentatively accept Hypothesis $C$ and illustrate turtles' position as shown in Figure 3.

The retention of $\mathrm{HoxC} 1$ in caecilians supports the Batrachia hypothesis

Because sharks, many teleost fishes, lobe-finned fishes all possess $\mathrm{Hox} \mathrm{C} 1$ but all tetrapod species examined before this study lack this gene, Kuraku and Meyer [22] deduced that tetrapod ancestors lost their $\mathrm{Hox} C 1$ gene when they diverged from lobe-finned fishes. However, our finding of HoxC1 in caecilians suggested that tetrapod ancestors actually retained $\mathrm{HoxC} 1$ gene but subsequently lost in different lineages. The presence of HoxC1 likely represents a "fish-style" Hox gene inventory and only basal tetrapod lineages have the possibility to retain this gene. Amphibians definitely branch first from the tetrapod tree and comprise of three distinct living groups: frogs, salamanders and caecilians [44]. The retention of HoxC1 in caecilians but not in frogs and salamanders implied that among the three living amphibian groups, caecilians are more distantly related to frogs and salamanders, supporting the Batrachia hypothesis (a frog+salamander clade) advocated by most recent molecular studies [45-48].

\section{Conclusions}

We performed a comprehensive PCR survey of Hox genes for six major sarcopterygian groups: lungfishes, 
caecilians, salamanders, snakes, turtles and crocodiles and clarified some uncertainties of birds' Hox gene inventory. Our study provided a more complete scenario for evolutionary dynamics of Hox genes along major sarcopterygian lineages. On the whole, Hox gene inventories of sarcopterygians are rather conserved with only little variations occurring in the anterior or posterior Hox paralogue groups. The Hox gene inventories of limbless caecilians and snakes largely resemble those of animals with less derived body morphology, suggesting changes to their body morphology were likely due to other modifications rather than changes to Hox gene numbers. In future, it is interesting to sequence the entire Hox clusters for these animals and our work can serve as basis for this purpose.

\section{Methods}

\section{Taxon sampling}

In order to obtain a broad overview of Hox gene variation in major sarcopterygian lineages, we focused on those groups whose Hox gene data were incomplete or missing when our research began. The following six species were selected for comprehensive Hox gene survey: Protopterus annectens (African lungfish) which represents another major group of extant lobe-finned fishes besides coelacanths; Ichthyophis bannanicus (Banna caecilian) and Batrachuperus tibetanus (Tibetan mountain salamander) representing caecilians and salamanders for the amphibian lineage; Naja atra (Chinese cobra), Pelodiscus sinensis (Chinese soft-shell turtle) and Crocodylus siamensis (Siamese crocodile) as the representative of snakes, turtles and crocodiles for the reptilian lineage, respectively. As we found some Hox gene variations among these group representatives, we selected additional 22 species, providing a broad evolutionary coverage for different animal groups, to test the observed Hox variation within certain group. Detailed information for all species used in this study is listed in Table 2 .

\section{PCR, cloning and sequencing of Hox genes}

We amplified fragments of Hox genes from genomic DNA by PCR using several combinations of degenerate primers flanking the homeobox or exon1 region (Table 1). In the comprehensive surveys for the group representatives, Hox genes were first divided into six paralogue group (PG) sets (PG1-7, PG1-10, PG11, PG12, PG13, PG14) for amplification. For some paralogue groups such as PG12 and PG13 which were difficult to amplify, more than one set of primers was used to increase the probability of successful amplification. If any members of PG1-10 was not initially retrieved with the general primers, e.g., HoxC5 of PG5 could not been found, a PG specific forward primer HoxF5S would be used; if the PG specific primers still failed to amplify the gene, a more specific primer HoxFC5 would be used to confirm its presence or absence. PG specific primers were also applied in the subsequent confirmation of Hox gene variations in the additional 22 species. We know that non-detection by PCR survey can not be interpreted definitively as a missing gene, but by trying more sets of primers and surveying more numbers of related species, the completeness of Hox gene PCR survey for a given animal group is expected to be high.

PCR was performed in $25 \mu \mathrm{l}$ reaction volumes with ExTaq DNA polymerase (Takara, Dalian) using the following cycling parameters: an initial denaturation step at $94^{\circ} \mathrm{C}$ for $4 \mathrm{~min}, 45$ cycles of $94^{\circ} \mathrm{C}$ for 30 s, $42-55^{\circ} \mathrm{C}$ for $1 \mathrm{~min}, 72^{\circ} \mathrm{C}$ for $30 \mathrm{~s}$, and a final extension step at $72^{\circ} \mathrm{C}$ for $10 \mathrm{~min}$. PCR products were purified by agarose gel extraction (Axygen, Suzhou) and cloned into a PMD19$\mathrm{T}$ vector (Takara, Dalian). Positive recombinant clones were identified by colony PCR and the PCR products were cleaned with ExoSap treatment and sequenced on an automated ABI3730 DNA sequencer.

\section{Sequence analysis}

Firstly, an alignment of homeobox regions of Hox genes from six well-studied vertebrate species was made. Hox genes of coelacanth (Latimeria menadoensis), frog (Xenopus tropicalis), chicken (Gallus gallus), lizard (Anolis carolinensis), mouse (Mus musculus) and human (Homo sapiens) were retrieved from GenBank upon availability. For some Hox genes of frog, lizard and chicken that can not be directly collected from GenBank, we identified their draft sequences by alignments with other vertebrates at the UCSC Genome Browser http://genome. ucsc.edu/. All the obtained sequences were cut down to $180 \mathrm{bp}$ of homeobox and aligned by ClustalX [49].

For each of the examined species, we compared all its obtained sequences against each other and identified a set of unique sequences for the species. These unique sequences were first screened for Hox gene fragments using BLAST searches in GenBank. Candidate sequences were then aligned to the aforementioned 6-species homeobox alignment, both at the protein and the nucleic acid level. Phylogenetic trees were generated by the Neighbor-Joining method implemented in the MEGA 4.0 [50] with either K2P (for nucleic acid) or JTT (for protein) distances. Supports for the nodes were evaluated by non-parametric bootstrap analyses of 1,000 replicates. The assignment of the candidate sequences were made based on their phylogenetic position at the protein or the nucleic acid level.

\section{Genome walking}

Because the homeobox regions we used are relatively short, some Hox gene fragments cannot be undoubtedly assigned to certain paralogue. To confirm the credibility of our assignments, we performed genome walking 
Table 2 List of species used in this study

\begin{tabular}{|c|c|c|c|c|}
\hline \multicolumn{2}{|c|}{ Taxonomy } & \multirow[t]{2}{*}{ Scientific name } & \multirow[b]{2}{*}{ used for PCR survey } & \multirow{2}{*}{$\begin{array}{l}\text { Collection locality (or specimen voucher } \\
\text { No.) }\end{array}$} \\
\hline & & & & \\
\hline Sarcopterygii & Dipnoi & Protopterus annectens & African lungfish & Pet trade \\
\hline \multirow[t]{2}{*}{ Amphibia } & Gymnophiona & Ichthyophis bannanicus* & Banna caecilian & Beiliu, Guangxi, China \\
\hline & Caudata & Batrachuperus tibetanus & Tibetan mountain salamander & Qingchuan, Sichuan, China \\
\hline \multirow[t]{3}{*}{ Reptilia } & Serpentes & Naja atra* & Chinese cobra & Shaoguan, Guangdong, China \\
\hline & Testudines & Pelodiscus sinensis & Chinese softshell turtle & Shaoguan, Guangdong, China \\
\hline & Crocodylia & Crocodylus siamensis & Siamese crocodile & Shenzhen, Guangdong, China \\
\hline \multicolumn{5}{|c|}{ Species used for Hox gene member validation } \\
\hline \multirow[t]{2}{*}{ Gymnophiona } & Caeciliidae & Gymnopis multiplicata* & Purple caecilian & MVZ Herps 228795 \\
\hline & Typhlonectidae & Typhlonectes natans* & Rubber eel & MVZ Herps 179733 \\
\hline \multirow[t]{2}{*}{ Caudata } & Salamandridae & Pachytriton brevipes & Chinese fat newt & Anji, Zhejiang, China \\
\hline & Hynobiidae & Batrachuperus yenyuanensis & Yenyuan stream salamander & Xichang, Sichuan, China \\
\hline \multirow[t]{2}{*}{ Serpentes } & Pythonidae & Python regius* & Ball python & Personal captivity \\
\hline & Leptotyphlopidae & Leptotyphlops blanfordii* & Blind snake & MVZ Herps 236621 \\
\hline \multirow[t]{8}{*}{ Squamata } & Dibamidae & Dibamus bourreti* & Bourret's blind skink & Hongkong, China \\
\hline & Gekkonidae & Hemidactylus bowringii & House Gecko & Guangzhou, Guangdong, China \\
\hline & Anguidae & Ophisaurus harti* & Hart's glass lizard & Pet trade \\
\hline & Scincidae & Typhlosaurus sp. ${ }^{*}$ & Legless skink & MVZ Herps 164850 \\
\hline & Blanidae & Blanus strauchi* & Anatolian worm lizard & MVZ Herps 230227 \\
\hline & Amphisbaenidae & Amphisbaena caeca* & Puerto Rican worm lizard & MVZ Herps 232753 \\
\hline & Anniellidae & Anniella pulchra* & California legless lizard & MVZ Herps 230670 \\
\hline & Bipedidae & Bipes biporus & Baja worm lizard & MVZ Herps 236257 \\
\hline \multirow[t]{4}{*}{ Testudines } & Podocnemididae & Podocnemis unifilis & $\begin{array}{l}\text { Yellow-spotted Amazon river } \\
\text { turtle }\end{array}$ & Pet trade \\
\hline & Carettochelyidae & Carettochelys insculpta & Pig-nosed turtle & Pet trade \\
\hline & Emydidae & Chrysemys picta & Painted turtle & MVZ Herps 241506 \\
\hline & & Trachemys scripta & Red-eared slider turtle & Commercial food source \\
\hline Crocodylia & Alligatoridae & Alligator sinensis & Chinese alligator & $\begin{array}{l}\text { Alligator Research Center, Xuanzhou, Anhui, } \\
\text { China }\end{array}$ \\
\hline \multirow[t]{3}{*}{ Aves } & Paleognathae & Struthio camelus & Ostrich & Commercial food source \\
\hline & Galliformes & Gallus gallus domesticus & Chicken & Commercial food source \\
\hline & Anseriformes & $\begin{array}{l}\text { Anas platyrhynchos var. } \\
\text { domestica }\end{array}$ & Domestic duck & Commercial food source \\
\hline
\end{tabular}

* Species that is limbless or only has limb remnants

(GW) to obtain the unknown sequence adjacent to the homeobox region towards $5^{\prime}$ or $3^{\prime}$ end of exon 2 . The homeobox-flanking regions are less conserved and more informative and thus can facilitate identification of the paralogue. The genome walking was carried out by using the Genome Walking Kit (Takara, Dalian) which is based on a TAIL-PCR technique. GW-specific primers were designed based on the candidate fragment sequences following the manufacture's guidance (available upon request).

\section{Sequence availability}

All sequences of Hox gene fragments identified in this paper are deposited in GenBank under accession numbers HQ441256 to HQ441561

\section{Additional material}

Additional file 1: Statistics of clones sequenced in each species and during the validation of $\operatorname{HoxCl}_{1} \operatorname{HoxC} 3, \operatorname{HoxD} 12$ and HoxB13.

\section{Acknowledgements}

We thank Ke Jiang for helping in some specimen collection and the MVZ Herpetology Collection for providing many valuable tissue samples. Three anonymous reviewers gave insightful comments on an earlier version of the manuscript. This work was supported by the Key Hatching Project of Sun Yat-Sen University (No. 1132833) and National Natural Science Foundation of China (No. 30900136) to PZ and the New Faculty Start-up Project of Sun YatSen University (No. 33000-3126175) to DL.

\section{Author details}

${ }^{1}$ State Key Laboratory of Biocontrol, Key Laboratory of Gene Engineering of the Ministry of Education, School of Life Sciences, Sun Yat-Sen University, 
Guangzhou 510275, China. ${ }^{2}$ Alligator Research Center of Anhui Province, Xuanzhou 242000, Anhui, China.

\section{Authors' contributions}

$\mathrm{DL}$ and PZ conceived the study. PZ designed the experiments. RW and JG carried out the PCR survey and the genome walking experiments. DL, PZ and RW analyzed the data. CW provided the alligator sample. DL, PZ and RW wrote the manuscript. All authors read and approved the final manuscript.

\section{Received: 9 July 2010 Accepted: 26 January 2011}

Published: 26 January 2011

\section{References}

1. Holland LZ, Albalat R, Azumi K, Benito-Gutiérrez E, Blow MJ, BronnerFraser M, Brunet F, Butts T, Candiani S, Dishaw LJ, Ferrier DE, GarciaFernàndez J, Gibson-Brown JJ, Gissi C, Godzik A, Hallböök F, Hirose D, Hosomichi K, Ikuta T, Inoko H, Kasahara M, Kasamatsu J, Kawashima T, Kimura A, Kobayashi M, Kozmik Z, Kubokawa K, Laudet V, Litman GW, McHardy AC, Meulemans D, Nonaka M, Olinski RP, Pancer Z, Pennacchio LA, Pestarino M, Rast JP, Rigoutsos I, Robinson-Rechavi M, Roch G, Saiga H, Sasakura Y, Satake M, Satou Y, Schubert M, Sherwood N, Shiina T, Takatori N, Tello J, Vopalensky P, Wada S, Xu A, Ye Y, Yoshida K, Yoshizaki F, Yu JK, Zhang Q, Zmasek CM, de Jong PJ, Osoegawa K, Putnam NH, Rokhsar DS, Satoh N, Holland PW: The amphioxus genome illuminates vertebrate origins and cephalochordate biology. Genome Res 2008, 18:1100-1111.

2. Kmita M, Duboule D: Organizing axes in time and space: 25 years of colinear tinkering. Science 2003, 301:331-333.

3. Carroll SB: Chance and necessity: the evolution of morphological complexity and diversity. Nature 2001, 409:1102-1109.

4. Ikuta T, Saiga H: Organization of Hox genes in ascidians: present, past, and future. Dev Dyn 2005, 233:382-389.

5. Irvine SQ, Carr JL, Bailey WJ, Kawasaki K, Shimizu N, Amemiya CT, Ruddle FH: Genomic analysis of Hox clusters in the sea lamprey Petromyzon marinus. J Exp Zool (Mol Dev Evol) 2002, 294:47-62.

6. Stadler PF, Fried C, Prohaska SJ, Bailey WJ, Misof BY, Ruddle FH, Wagner GP: Evidence for independent Hox gene duplications in the hagfish lineage: a PCR-based gene inventory of Eptatretus stoutii. Mol Phylogenet Evol 2004, 32:686-694.

7. Fried C, Prohaska SJ, Stadler PF: Independent Hox-cluster duplications in lampreys. J Exp Zool (Mol Dev Evol) 2003, 299:18-25.

8. Kim CB, Amemiya C, Bailey W, Kawasaki K, Mezey J, Miller W, Minoshima S, Shimizu N, Wagner G, Ruddle F: Hox cluster genomics in the horn shark, Heterodontus francisci. Proc Natl Acad Sci USA 2000, 97:1655-1660.

9. Ravi V, Lam K, Tay BH, Tay A, Brenner S, Venkatesh B: Elephant shark (Callorhinchus milii) provides insights into the evolution of Hox gene clusters in gnathostomes. Proc Natl Acad Sci USA 2009, 106:16327-16332.

10. Oulion S, Debiais-Thibaud M, Aubenton-Carafa YD, Thermes C, Da Silva C, Bernard-Samain S, Gavory F, Wincker P, Mazan S, Casane D: Evolution of Hox gene clusters in gnathostomes: insights from a survey of a shark (Scyliorhinus canicula) transcriptome. Mol Biol Evol 2010.

11. Longhurst TJ, Joss JMP: Homeobox genes in the Australian lungfish, Neoceratodus forsteri. J Exp Zool (Mol Dev Evol) 1999, 285:140-145.

12. Koh EGL, Lam K, Christoffels A, Erdmann MV, Brenner S, Venkatesh B: Hox gene clusters in the Indonesian coelacanth, Latimeria menadoensis. Proc Natl Acad Sci USA 2003, 100:1084-1088.

13. Amemiya CT, Powers TP, Prohaska SJ, Grimwood J, Schmutz J, Dickson M, Miyake T, Schoenborn MA, Myers RM, Ruddle FH, Stadler PF: Complete HOX cluster characterization of the coelacanth provides further evidence for slow evolution of its genome. Proc Natl Acad Sci USA 2010, 107:3622-3627.

14. Hoegg S, Meyer A: Hox clusters as models for vertebrate genome evolution. Trends Genet 2005, 21:421-424.

15. Di-Poï N, Montoya-Burgos Jl, Duboule D: Atypical relaxation of structural constraints in Hox gene clusters of the green anole lizard. Genome Res 2009, 19:602-610.

16. Aparicio S, Chapman J, Stupka E, Putnam N, Chia JM, Dehal P, Christoffels A, Rash S, Hoon S, Smit A, Gelpke MD, Roach J, Oh T, Ho IY, Wong M, Detter C, Verhoef F, Predki P, Tay A, Lucas S, Richardson P, Smith SF, Clark MS, Edwards YJ, Doggett N, Zharkikh A, Tavtigian SV, Pruss D,
Barnstead M, Evans C, Baden H, Powell J, Glusman G, Rowen L, Hood L, Tan YH, Elgar G, Hawkins T, Venkatesh B, Rokhsar D, Brenner S: Wholegenome shotgun assembly and analysis of the genome of Fugu rubripes. Science 2002, 297:1301-1310.

17. Jaillon O, Aury JM, Brunet F, Petit JL, Stange-Thomann N, Mauceli E, Bouneau L, Fischer C, Ozouf-Costaz C, Bernot A, Nicaud S, Jaffe D, Fisher S, Lutfalla G, Dossat C, Segurens B, Dasilva C, Salanoubat M, Levy M, Boudet N, Castellano S, Anthouard V, Jubin C, Castelli V, Katinka M, Vacherie B, Biémont C, Skalli Z, Cattolico L, Poulain J, De Berardinis V, Cruaud C, Duprat S, Brottier P, Coutanceau JP, Gouzy J, Parra G, Lardier G, Chapple C, McKernan KJ, McEwan P, Bosak S, Kellis M, Volff JN, Guigó R, Zody MC, Mesirov J, Lindblad-Toh K, Birren B, Nusbaum C, Kahn D, RobinsonRechavi M, Laudet V, Schachter V, Quétier F, Saurin W, Scarpelli C, Wincker P, Lander ES, Weissenbach J, Roest Crollius H: Genome duplication in the teleost fish Tetraodon nigroviridis reveals the early vertebrate proto-karyotype. Nature 2004, 431:946-957.

18. Kurosawa G, Takamatsu N, Takahashi M, Sumitomo M, Sanaka E, Yamada K, Nishii K, Matsuda M, Asakawa S, Ishiguro H, Miura K, Kurosawa Y, Shimizu N, Kohara Y, Hori H: Organization and structure of Hox gene loci in medaka genome and comparison with those of pufferfish and zebrafish genomes. Gene 2006, 370:75-82.

19. Hoegg S, Boore J, Kuehl JV, Meyer A: Comparative phylogenomic analyses of teleost fish Hox gene clusters: lessons from the cichlid fish Astatotilapia burtoni. BMC Genomics 2007, 8:317.

20. Kasahara M, Naruse K, Sasaki S, Nakatani Y, Qu W, Ahsan B, Yamada T, Nagayasu Y, Doi K, Kasai Y, Jindo T, Kobayashi D, Shimada A, Toyoda A, Kuroki Y, Fujiyama A, Sasaki T, Shimizu A, Asakawa S, Shimizu N, Hashimoto S, Yang J, Lee Y, Matsushima K, Sugano S, Sakaizumi M, Narita T, Ohishi K, Haga S, Ohta F, Nomoto H, Nogata K, Morishita T, Endo T, Shin-I T, Takeda H, Morishita S, Kohara Y: The medaka draft genome and insights into vertebrate genome evolution. Nature 2007, 447:714-719.

21. Moghadam HK, Ferguson MM, Danzmann RG: Evolution of Hox clusters in Salmonidae: a comparative analysis between Atlantic salmon (Salmo salar) and rainbow trout (Oncorhynchus mykiss). J Mol Evol 2005, 61:636-649.

22. Kuraku S, Meyer A: The evolution and maintenance of Hox gene clusters in vertebrates and the teleost-specific genome duplication. Int J Dev Biol 2009, 53:765-773.

23. Richardson MK, Crooijmans RP, Groenen MA: Sequencing and genomic annotation of the chicken (Gallus gallus) Hox clusters, and mapping of evolutionarily conserved regions. Cytogenet Genome Res 2007, 117:110-119.

24. Mannaert A, Roelants K, Bossuyt F, Leyns L: A PCR survey for posterior Hox genes in amphibians. Mol Phylogenet Evol 2006, 38:449-458.

25. Di-Poï N, Montoya-Burgos Jl, Miller H, Pourquié O, Milinkovitch MC, Duboule D: Changes in Hox genes' structure and function during the evolution of the squamate body plan. Nature 2010, 464:99-103.

26. Woltering JM, Vonk FJ, Müller H, Bardine N, Tuduce IL, de Bakker MAG, Knöchel W, Sirbu IO, Durston AJ, Richardson MK: Axial patterning in snakes and caecilians: Evidence for an alternative interpretation of the Hox code. Dev Biol 2009, 332:82-89.

27. Cohn MJ, Tickle C: Developmental basis of limblessness and axial patterning in snakes. Nature 1999, 399:474-479.

28. Davis AP, Capecchi MR: A mutational analysis of the $5^{\prime}$ HoxD genes: dissection of genetic interactions during limb development in the mouse. Development 1996, 122:1175-1185

29. Dollé $P$, Dierich $A$, LeMeur M, Schimmang $T$, Schuhbaur $B$, Chambon $P$, Duboule D: Disruption of the Hoxd-13 gene induces localized heterochrony leading to mice with neotenic limbs. Cell 1993, 75:431-441.

30. Meyer A, Zardoya R: Recent advances in the (molecular) phylogeny of vertebrates. Annu Rev Ecol Evol Syst 2003, 34:311-338.

31. Luo J, Stadler PF, He S, Meyer A: PCR survey of Hox genes in the goldfish Carassius auratus auratus. J Exp Zool (Mol Dev Evol) 2007, 308:250-258.

32. Gauthier J, Kluge AG, Rowe T: Amniote phylogeny and the importance of fossils. Cladistics 1988, 4:105-209.

33. Carroll RL: Vertebrate Paleontology and Evolution New York: Freeman; 1988.

34. Laurin M, Reisz RR: A reevaluation of early amniote phylogeny. Zool J Linn Soc 1995, 113:165-223

35. Werneburg I, Sánchez-Villagra MR: Timing of organogenesis support basal position of turtles in the amniote tree of life. BMC Evol Biol 2009, 9:82. 
36. Rieppel O, deBraga M: Turtles as diapsid reptiles. Nature 1996, 384:453-455.

37. Rieppel O, Reisz RR: The origin and early evolution of turtles. Annu Rev Ecol Syst 1999, 30:1-22.

38. Zardoya R, Meyer A: Complete mitochondrial genome suggests diapsid affinities of turtles. Proc Natl Acad Sci USA 1998, 95:14226-14231.

39. Hedges SB, Poling LL: A molecular phylogeny of reptiles. Science 1999, 283:998-1001.

40. Cao Y, Sorenson MD, Kumazawa Y, Mindell DP, Hasegawa M: Phylogenetic position of turtles among amniotes: evidence from mitochondrial and nuclear genes. Gene 2000, 259:139-148.

41. Rest JS, Ast JC, Austin CC, Waddell PJ, Tibbetts EA, Hay JM, Mindell DP: Molecular systematics of primary reptilian lineages and the tuatara mitochondrial genome. Mol Phylogenet Evol 2003, 29:289-297.

42. Imabe N, Hara Y, Kumazawa Y, Shibamoto K, Saito Y, Miyata T, Katoh K: Sister group relationship of turtles to the bird-crocodilian clade revealed by nuclear DNA-coded proteins. Mol Biol Evol 2004, 22:810-813.

43. Hugall AF, Foster R, Lee MSY: Calibration choice, rate smoothing, and the pattern of tetrapod diversification according to the long nuclear gene RAG-1. Syst Biol 2007, 56:543-563.

44. Duellman WE, Trueb L: Biology of Amphibians New York: McGraw-Hill; 1994.

45. Zardoya R, Meyer A: On the origin of and phylogenetic relationships among living amphibians. Proc Natl Acad Sci USA 2001, 98:7380-7383.

46. Zhang P, Zhou H, Chen YQ, Liu YF, Qu LH: Mitogenomic perspectives on the origin and phylogeny of living amphibians. Syst Biol 2005, 54:391-400,

47. Frost DR, Grant T, Faivovich J, Bain RH, Haas A, Haddad CFB, De Sá RO, Channing A, Wilkinson M, Donnellan SC, Raxworthy CJ, Campbell JA, Blotto BL, Moler P, Drewes RC, Nussbaum RA, Lynch JD, Green DM, Wheeler WC: The amphibian tree of life. Bull Am Mus Nat Hist 2006, 297:1-370

48. Roelants K, Gower DJ, Wilkinson M, Loader SP, Biju SD, Guillaume K, Moriau L, Bossuyt F: Global pattern of diversification in the history of modern amphibians. Proc Natl Acad Sci USA 2007, 104:887-892.

49. Thompson JD, Higgins DG, Gibson TJ: ClustalW: improving the sensitivity of progressive multiple sequence alignment through sequence weighting, positions-specific gap penalties and weight matrix choice, ClustalX Version 1.64. Nucleic Acids Res 1994, 22:4673-4680.

50. Tamura K, Dudley J, Nei M, Kumar S: MEGA4: Molecular Evolutionary Genetics Analysis (MEGA) software version 4.0. Mol Biol Evol 2007, 24:1596-1599.

51. Hedges SB, Kumar S: The Timetree of Life New York: Oxford University Press; 2009.

doi:10.1186/1471-2148-11-25

Cite this article as: Liang et al:: A general scenario of Hox gene inventory variation among major sarcopterygian lineages. $B M C$ Evolutionary Biology 2011 11:25.

\section{Submit your next manuscript to BioMed Central and take full advantage of:}

- Convenient online submission

- Thorough peer review

- No space constraints or color figure charges

- Immediate publication on acceptance

- Inclusion in PubMed, CAS, Scopus and Google Scholar

- Research which is freely available for redistribution

Submit your manuscript at www.biomedcentral.com/submit
Biomed Central 